\title{
Ownership Structure and Its Impact on Dividend Policy: A Case of Non-Financial Companies in Pakistan
}

\author{
ABDUL LATIF \\ Phd-Scholar, Abdul Wali Khan University, Mardan \\ Abdullatif89@gmail.com \\ MUHAMMAD TAHIR KHAN \\ Lecturer, Abdul Wali Khan University, Mardan \\ mtahir@awkum.edu.pk \\ MUHAMMAD NISAR KHAN \\ Lecturer, Bacha Khan University, Charsadda
}

\begin{abstract}
This article focus on one of important corporate decision that can have a great impact on the sentiments of the investor's i.e. corporate dividend policy. This study investigates the determinants of the corporate dividend policy in the context of agency relation. The analysis of the study has based on the random sample of eighty firms from the listed companies in Pakistan, for the period of eight years ranging from 2003 to 2012. Stepwise multiple regressions have used to investigate for the relationship of ownership variables with the dividend payouts. The empirical results suggested that there has a negative relationship between the dividend payouts and managerial share ownership and thus these are alternative tools that can be used to minimize the agency problem. And also where there has positive relationship between the institutional suggested that the higher has their shareholdings the higher will be the firm dividend payouts that will leads to less availability of the cash flows with the opportunities managers to expropriate the shareholders wealth.
\end{abstract}

Key Words: Dividend Policy, Ownership Structure, Pakistan Stock Exchange

\section{Introduction}

Why the firms pay dividend? Since for long time, this question has given a lot of consideration and focus in the research. In corporate policies giving dividend to its shareholders considered the more important policy. Dividend policy also plays important role and control medium and exchange to reduce the conflicting interest of managers and shareholders, because managers want to retain earnings for the future growth of the firms. And the shareholders are interested in getting dividends. Jensen (1986) and Rozeff (1982) found that if the firm minimizes the agency problem so they will be using the dividend payout policy. According to authors, if the firms do not pay dividends to their shareholders, the mangers will create such an environment that they start using the resources for their own benefits. It helps the firms by handling the dividend policy how they can control agency cost. Jensen (1986) argued that to minimize the managerial 
control over resources, the firm start paying dividends to their share holders. Dividend policy is not limited to reduce the agency cost but it will also acts as a signaling theory to give the company information to the shareholders to evaluate the firm's performance. Carvalhal-da-Silva and Leal (2004) argued that to give information about two significant things ownership structure is very important to determine the efficiency of the markets. First the information about the agency problem will extracted from the management in firms, second it will show the risk diversification extent of shareholders. The decision to pay dividend the role of Institutional ownership also plays an important role. Institutional ownership (i.e. percentage of institutional shareholding in corporation such as banks, mutual funds, pension funds etc). To control agency problem these stakeholders also plays $n$ crucial role in dividend payment. Short (2002) explain the significant connection between institutional ownership and dividend policy. On one hand some researcher's shows positive relationship between institutional ownership and dividend policy and some shows negative alliance between dividend policy and institutional ownership.

The core aim of this research is to find out relation between ownership structure and its impact on dividend policy of non - financial listed companies in Pakistan. Numerous preceding has been done on this topic but this focus to find out the association between the two variables with the help of the reference of Pakistani listed companies Further this study focuses on the relationship of ownership structure and dividend policy. As ownership structure is a corporate governance mechanism to monitor the effectiveness of the firm and to ensure that the interests of the shareholders are met. This study will help investors to find out how the determinants of ownership structure effect the firm decision about dividends. This research article investigates the impact of the firm's ownership structure and its impact on dividend payout policies in Pakistan by giving that statistical support. The reason of our study is find out the correlation of the dividend policy with the managerial, individual, institutional ownership, board size, firm size and leverage. Pakistan economy is an emerging economy having diverse cultural, lifestyle, religion, traits, etc for this our findings will different as compared to developed economies. This paper arranged as follows. First part includes a healthy introduction. Second part provides a frame work of brief literature; also different hypothesis is developed in literature. Third part includes data collection and theoretical framework. Fourth part includes methodology sach as descriptive statistics, correlation, ANOVA test and coefficient of the study. Fifth part includes the conclusion and recommendations.

\subsection{Research Questions}

This research finds out the Ownership Structure and its impact on dividend policy: A case from non-financial listed companies in Pakistan

\subsection{Research Objectives}

The core aim this research is to find out the relation between ownership structure and its impact on dividend policy from listed non - financial companies in Pakistan. Numerous preceding has been done on this topic but this focus to find out the association between the two variables with the help of the reference of Pakistani listed companies.

\subsection{Significance of the Study}

This study focuses on the relationship of ownership structure and dividend policy. As ownership structure is a corporate governance mechanism to monitor the 
effectiveness of the firm and to ensure that the interests of the shareholders are met. This study will help investors to find out how the determinants of ownership structure effect the firm decision about dividends.

\section{Literature Review}

Ownership structure is one of the main influential factors for company policies. For making corporate policies decisions with respect to dividend are one of the fundamental components (Kouki \& Guizani, 2009). Therefore, dividend policy and ownership structure have a significant relation is expected between the two. Miller \& Modigliani (1961) put their efforts on the fundamental work on dividend policy; suggest that dividend policy is not relevant. So any change that makes in dividend policy is not a thing of value at all, since the stockholder can replicate purchasing and selling of equity by any desired stream of payments. The debate on the dividend policy from the last fifty four years makes a lot of contribution and developed a significant body in literature. In which some of the researchers shows that dividend payments has a positive impact on the value of firm. But also some of the researcher has argued that dividend payments firm value negatively.

\subsection{Institutional Ownership and Dividend Policy}

Dividend is considered as reward of shareholder of their contribution for bearing relevant risk and raising fund for the company. To divide and distribute earnings among shareholder the management of a company regulates dividend policy for the shareholder of their investment. The dividend policy has a crucial impact on the firm's value because the firm has to maintain dividend policies \& growth policies in a state of equilibrium. Large investors like Institutional investors such as banks, insurance, pension funds financial institution and some other like these firms which were associated with the mentioned categories of institutions Koh (2003). Many other researchers showed a relationship between dividend policy and management ownership Rozeff (1982). Researches show that dividend policy and institutional ownership have significant relationship short et, al (2002). On one hand researchers showed that dividend policy and institutional there is positive relationship between them. But on other side ownership management and dividend policy are having a negative relationship. Institutional owners have the capability to invest more in different corporations. McConnell \& Servaes (1990) suggest that with the existence of institutional shareholders manager's entrenchment would be more difficult. Therefore, in the presence of institutional owners, reducing of agency cost would be less likely to use dividend as a mean. Aoki (1984) \& Lowenstein (1988) suggest that in the long-term interests of the firms and for the owners of those firms. Institutional shareholders are a powerful and positive force for pushing corporate managements. Maury \& Pajuste (2002) gathered data from the stock exchange of Helsinki in Finland, conclude that dividend policy have not significant impact on the division of ownership and havin hold through voting shares and design of pyramid. The conclusion of this study is that dividend payout policy affects the firm control structure and high has a negative impact on the dividend payout decision are negatively affected by institutional ownership.

\subsection{Dividend policy and Managerial ownership}

Harada \& Nguyen (2009), Short et al. (2002) and karathanassis et al. (2004) 
showed in their research that managerial ownerships refers to the company's management that holdes whole \% of equity, that may highlight either their natural presence or part in the Board Of Directors. Dummy variable is used in the empirical analysis (MAN) which equals to (1). When managerial ownership has higher $\%$ age than mean $\%$ age from sample, so it will becomes (0). Otherwise Manos (2002) \& Harada (2009) conclude a negative bond between percentage ownership of the share holders to participate in the company management Stouraitis \& Wu (2004) examined the relationship of structure of ownership on policy of dividend of Japanese companies. Managerial ownership and ownership of banks is having positive impact on dividend yield especially for the firms having low growth. However (Shah \& Hussian, 2011) the study suggest that managerial ownership and dividend payout is having positive and significant relationship. But it has a positive significant impact between ownership structure and dividend policy. Chen and Steiner (1999) find an important contribution by this field of research to find how managerial ownership relates to dividend policy, risk taking and debt policy. The results of this study showed that managerial ownership helps to minimize the agency conflicts between managers and external shareholders.

\subsection{Agency theory}

The first time (Jensen and Meckling, 1976) discussed that information asymmetry between inside ownership and outside may lead to agency cost. The principle of agency theory is that it's the conflict of interest between owners and managers. An agency relationship takes place when the agents perform some duties on the behalf of principles. (Wiberg, 2008) argued that the alignment between ownership and control incentives are depending upon dividend policies. And agency problem arise that the diversion of these incentives will affect the dividend payout policies. Short et al, (2002) investigated the association between dividend policy and ownership structure on UK based companies the first result showed that the UK institutional framework and ownership structure is changed from US, and second results showed that for reducing the agency cost dividend policy perform a crucial role, which have raised a conflict of interest between the two parties.

\subsection{Corporate governance and dividend payout}

The discussion of corporate governance was started in early 1980s, because of the American managers have ignored the interest of shareholders due to which the share price moving downward. For many years work on corporate governance has been done, but mostly the greater work on corporate governance has been done by the organization for economic co-operation and development (OECD). Government of OECD members countries have interest to do better work of the interest for their citizens. In 1999 the OECD has published a paper for corporate governance, which first international code of corporate governance. In last few years corporate governance has become an important subject for the large interest the firm with later generation of family share has lower level of dividends. He also suggests that early generation of family ownership in corporate governance is effective, and the generation of family ownership is ineffective of shaping the design of dividend payout policy. (Kumar, 2006) investigated the relationship between dividend payout and corporate governance for a panel data of Indian firms from 1994 to 2000. He explained the difference of dividend behavior with the help of firm 
financial structure, earning trends, dividend history, and the ownership structure. $\mathrm{He}$ found negative relationship with debt- equity ratio and positive relationship between dividend and earning trends. Ayub (2005) examined the role of corporate governance with related factors to design dividend policy.

\subsection{Research Hypotheses}

On the basis of above studied literature we have develop these research hypotheses.

The major hypotheses are as follows

Ho: there is no significant relationship between ownership structure and Dividend payout H1: there is significant relationship between ownership structure and Dividend payout Further sub-hypotheses are

1) There is a significant relationship between the institutional ownership and dividend payout.

2) There is a significant relationship between managerial ownership and dividend payout.

3) There is a significant relationship between individual ownership and dividend payout.

4) There is a significant relationship between board size and dividend payout

5) There is a significant relationship between size of firm and dividend payout

6) There is a significant relationship between leverage and dividend payout.

\section{Data Collection and Methodology}

\subsection{Data collection}

The source of data collection was from the listed companies of Pakistan stock exchange (PSX) analysis report, websites, financial sheet analysis, balance sheet analysis, individual firm website and report of the state bank.

\subsection{Sample Size}

The sample of this study includes randomly selected eighty (80) companies from listed companies in Pakistan and annually data were collected from the period of ten years from 2003 to 2012. The sample mainly consists of non- financial firms from different sectors such as oil and gas, cement, textile, pharmaceutical, chemical, durable goods, transportation etc Panel data is used for ownership structure variables over dividend policy in Pakistani listed companies. The data is taken from the annual report, KSE website, open doors etc for the non - financial listed companies for the time period of ten (10) years from $2003-2010$. This study used different statistical test descriptive statistics, ANOVA test, correlation, and Regression analysis.

\subsection{Variables}

The variables consist of dependent and independent variables. Dependent variables consist of Dividend policy and independent variables consist of managerial ownership, individual ownership, institutional ownership, board size, leverage and firm size.

\subsubsection{Independent Variables}

As mentioned above independent variables are consist of managerial ownership, individual ownership, institutional ownership, board size, leverage and firm size and it is measured through linear regression. 


\subsubsection{Dependent variable:}

The study used dividend return as dependent variable to check the ownership structure and to check whether dividend return is effected by above mentioned independent variables or not.

\subsubsection{Variables of the Study}

\begin{tabular}{|l|l|}
\hline Variables & Calculation base Or Measurement \\
\hline $\begin{array}{l}\text { Managerial ownership } \\
\text { Individual ownership } \\
\text { Institutional ownership }\end{array}$ & $\begin{array}{l}\text { \%age of shares held by directors, executives, managers etc } \\
\text { Firm Size } \\
\text { Leverage } \\
\text { Board size } \\
\text { Dividend }\end{array}$ \\
$\begin{array}{l}\text { \%age share held by individual and general public } \\
\text { companies etc }\end{array}$ \\
$\begin{array}{l}\text { Log of total assets. } \\
\text { Long term debt/total assets } \\
\text { Total number of directors (dependent and independent) both } \\
\text { Average dividend per share }\end{array}$ \\
\hline
\end{tabular}

\section{Research model:}

Div $=\alpha+\beta_{1}$ MGR $+\beta_{2}$ IND $+\beta_{3}$ INS $+\beta_{4}$ BoardSZ $+\beta_{5}$ Lev $+\beta_{5}$ SZ

Where:

Div $=$ Dividend

MGR = Managerial Owner ship

IND = Independent ownership

INS = Institutional Ownership

Board SZ = Board size

Lev $=$ Leverage

$\mathrm{SZ}=$ Size of firm

\section{Results}

The analysis section is used to determine how these variables are interconnected with each other, for this different test is used. Descriptive statistics is used. The ANOVA test is used in this study, Correlation analysis of the ownership structure and control variables and the coefficient of variables is used.

Table 2: Descriptive Statistics

\begin{tabular}{|l|lll|}
\hline \multicolumn{2}{l}{ Mean } & Std. Deviation & N \\
\hline Div & $5.090674373796 \mathrm{E} 0$ & $2.0198722502367 \mathrm{E} 0$ & 519 \\
Lev & .497555805312 & .3386381009690 & 519 \\
SZ & $8.91651192505 \mathrm{E} 0$ & $1.970453845701 \mathrm{E} 0$ & 519 \\
MGR & .330924855491 & $1.6217041158967 \mathrm{E} 0$ & 519 \\
IND & $1.54689788054 \mathrm{E} 0$ & $5.644239333655 \mathrm{E} 0$ & 519 \\
INS & $1.48460500963 \mathrm{E} 0$ & $6.517059510261 \mathrm{E} 0$ & 519 \\
\hline
\end{tabular}




\begin{tabular}{|l|lll|}
\hline \multicolumn{2}{|l}{ Mean } & Std. Deviation & N \\
\hline Div & $5.090674373796 \mathrm{E} 0$ & $2.0198722502367 \mathrm{E} 0$ & 519 \\
Lev & .497555805312 & .3386381009690 & 519 \\
SZ & $8.91651192505 \mathrm{E} 0$ & $1.970453845701 \mathrm{E} 0$ & 519 \\
MGR & .330924855491 & $1.6217041158967 \mathrm{E} 0$ & 519 \\
IND & $1.54689788054 \mathrm{E} 0$ & $5.644239333655 \mathrm{E} 0$ & 519 \\
INS & $1.48460500963 \mathrm{E} 0$ & $6.517059510261 \mathrm{E} 0$ & 519 \\
\hline BoardSZ & $9.175337187 \mathrm{E} 0$ & $2.0377917471 \mathrm{E} 0$ & 519 \\
\hline
\end{tabular}

Table 3: Correlations

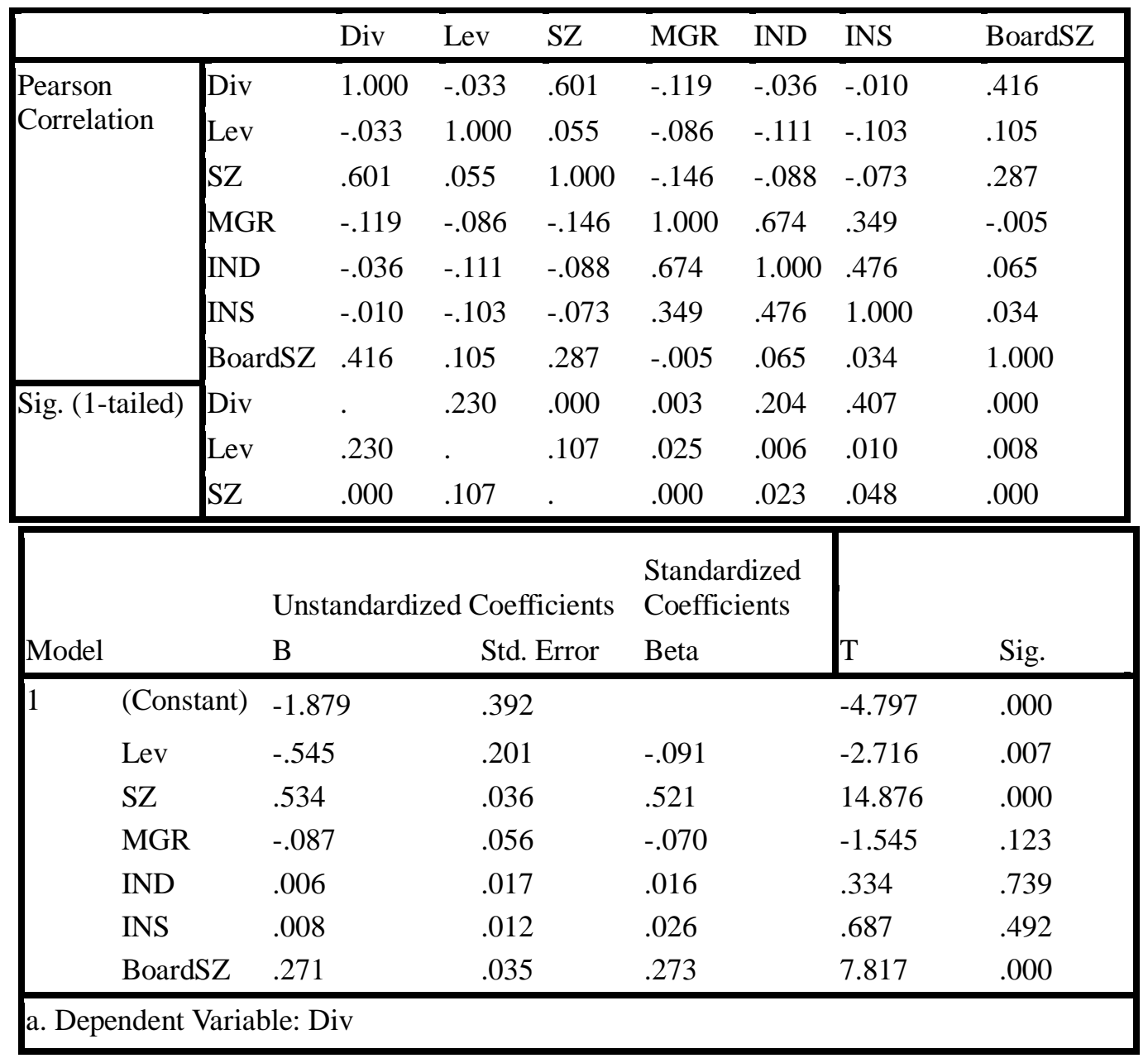




\section{Discussion of Regression Analysis}

Regression table will give information about the effect of independent variable that is leverage, size, managerial ownership, individual ownership, institutional ownership and board size on dependent variable that is dividend. The standardized Coefficients of Beta shows the value that if one unit change occurs in dependent variable so how much change will occur in independent value. The standardized Coefficients Beta of Lev is (-.091) it means that if one unit of dividend is increased the Lev value will be decreased by (-.091). The standardized coefficients Beta of firm size are (.521) it means that if one unit of dividend is increased the firm size will also be increase by (.521). The standardized coefficients beta of managerial ownership is (-.070) which means that if dividend units is increased by one unit the managerial ownership will be decreased by (-.070). The standardized coefficients Beta of individual ownership is (.016) which means that if the dividend is increase by one unit the individual ownership will also be increased by (.016). The standardized coefficients of Beta of institutional ownership are (.026) which means that if dividend is increase by one unit, the individual ownership will also be increase by (.026). The standardized coefficients Beta of Board Size is (.273) which means that if dividend is increase by one unit the Board Size will also be increase by (.273). The table shows that the $\mathrm{P}$ value of the leverage .007 which is less than then .05 which mean that there is effect of leverage on dividend which confirms the acceptance of the alternative hypothesis that is there is a significant relationship between leverage and dividend payout. The $\mathrm{P}$ value of the size that is size of the firm is .000 which is less than 0.05 which mean that there is effect of size of the firm on the dividend which confirms the acceptance of the alternatives hypothesis that is there is a significant relationship between size of firm and dividend payout.

The table shows that the $\mathrm{P}$ value of the managerial ownership is .123 which is greater than 0.05 which mean that there is no effect of the managerial ownership on dividend which confirms the acceptance of the null hypothesis that is that there is insignificant relationship between managerial ownership and dividend payout. The table shows that the $\mathrm{P}$ value of the individual ownership is .739 which is greater than 0.05 which mean that there is no effect of individual ownership on dividend which confirms the acceptance of the null hypothesis that is there is insignificant relationship between individual ownership and dividend payout. The table shows that the $\mathrm{P}$ value of the institutional ownership is .492 which is greater than 0.05 which mean that there is no effect of institutional ownership on dividend which confirms the acceptance of the null hypothesis that there is insignificant relation between institutional ownership and dividend payout. The table shows that the $\mathrm{P}$ value of the board size is .000 which means that there is effect of board size on dividend which confirms the acceptance of the hypothesis which shows that there is significant relationship between board size and dividend policy.

\subsection{Conclusion}

This research contributes on the ongoing debate about the role of ownership structure with dividend policy. It examined the role of ownership structure with dividend policy in Pakistani context, a country with unique environmental characteristics. Non financial listed Pakistani companies (Karachi stock exchange) is used in the sample of 
this research paper. To shed the light of Pakistan context of emerging markets to find the association of dividend policy and ownership between the two. This study has examined eighty (80) non - financial listed companies in Pakistan. The panel data for time period is 2003 to 2012, to examine the relationship of ownership structure on dividend policy. In this study four regression models is used. The results demonstrated that institutional ownership have a negative association with dividend policy. It shows that role of institutional investors is less usage from dividend as a signal of firm good performance. These results are same with (Jain, 2007) and (Barcley et al. 2006). Based on the other findings the managerial ownership is insignificantly associated with dividend payout. It is because of the managers owners have little contribution in the shareholdings pattern in Pakistani firms so they cannot affect the dividend pay-out. Other finding shows that the size of the firm and dividend payout has positive relation between them. It indicates that increasing the size of the firms will give more dividends to its shareholders. In corporate dividend policy, ownership structure plays an important role, while agency issues will be minimized through agency cost. As a disciplining for the managers dividend is used as a control device to the opportunistic behavior. Therefore increases the managerial will reduce the problem associated with dividend, because the shareholders interest will be getting high as they seen the portion of managers, directors are high in the shareholding pattern.

\section{References}

Afza, T., \& Mirza, H. H. (2010). Ownership Structure and Cash Flows As Determinants of Corporate. International Business Research , 3 (3), 210-221.

Ahmed, H., \& Javid, A. (2009). Dynamics and Determinants of Dividend Policy in Pakistan: Evidence from Karachi Stock Exchange Non Financial Firms. International Journal of Finance and Economics (25), 148-171

Ang ,J. S., Cole, R. A. \& Lin, J. W. (2000). Agency costs and ownership structure. The Journal of Finance, Vol. 1, pp 81-105

Ayub, M. (2005). Corporate Governance and Dividend Policy. Pakistan Economic and Social Review 1 XLIII (2005): pp. 115-128.

Aoki, M. (1984). The Cooperative Theory of the Firm, Clarendon Press

Barclay, M. J., Smith, C. W. \& Watts, R. L. (1995). The Determinants of Corporate Leverage and Dividend Policies. Journal of Applied Corporate Finance 7(4), 419.

Benartzi, S., Michaely, R. \& Thaler, R. (1997). Do Changes in Dividends Signal the future or the Past. The Journal of Finance L I I , 1007-1034.

Brennan, M. J. (1995). A Plain Man's Response to Professor Jensen. Andersen Graduate School of Management, University of California, Working Paper.

Brennan, M. J. (1995). Corporate Finance Over the Past 25 Years. Financial Management 24, 9-22.

Carvalhal-da-Silva, André L. \& Leal, Ricardo P. C. (2004). Corporate Governance and Value in Brazil (and in Chile). Frontiers in Finance and Economics, Vol. 1(1), pages $1-16$

Chen, C. R., \& Steiner, T. L. (2005). Managerial Ownership and Agency Conflicts: A Nonlinear Simultaneous Equation Analysis of Managerial Ownership, Risk 
Taking, Debt Policy, and Dividend Policy. The Financial Review, Volume 34, Issue 1, 19-136. http://dx.doi.org/10.1111/j.1540-6288.1999.tb00448.x

Crutchley, C. E., \& Hansen, R. H. (1989). A Test of the Agency Theory of Managerial Ownership, Corporate Leverage and Corporate Dividends. Financ. Manage, 18 (4): $36-46$.

Easterbrook, F. H. (1984). Two Agency Cost Explanations of Dividends. American Economic Review, 74 (4), 650-659.

Fama, E. F. \& French, K. R. (2002). Testing Trade-Off and Peking Order Predictions Ab out Dividends and Debt, Review of Financial Studies, 15(1), 1-33.

Harada, K. \& Nguyen, P. (2006). Ownership concentration, agency conflicts, and dividend policy in Japan. Journal of Finance, Vol. 55, pp. $1-33$.

Himmelberg, C. P., Hubbard, R. G. \& Palia, V. (1999). Understanding the determinants of Ownership and the link between Ownership and Performance. Journal of Financial

Economics 53, 353-384

Jensen, M. (1986). Agency cost of free-cash-flow, corporate finance, and takeovers. AM. Econ. Rev., 76:323-329

Jensen, M. C., \& Meckling, W. (1976). Theory of the Firm: Managerial Behavior, Agency Costs, and Ownership Structure. J. Financ. Econ.,3: 305-360.

Jensen, G., Solberg, D. \& Zorn, T. (1992). Simultaneous determination of insider ownership, debt, and dividend policies. J. Financ. Quant. Anal., 27: 247-263.

Kang, J. \& Shivdasani, A. (1995). Firm Performance, Corporate Governance, and Top Executive Turnover in Japan. Journal of Financial Economics 38, 29-58

Karathanassis, G. \& Drakos, A. (2004). A Note on Equity Ownership and Corporate Value in Greece , managerial and Decision Economics, 25 (8), 537-547

Kumar, J. (2003). Ownership Structure and Dividend Payout Policy in India, Indira Gandhi Institute of Development Research, http://papers.ssrn.com

Kumar, P. (2006). Shareholder-Manager Conflict and the Information Content of Dividends. Review of Financial Studies 1(2), 111136

Kouki, M. \& Guizani, M. (2009). Corporate Governance and dividend policy in Poland. Warsaw School of Economics, World Economy Research Institute, Al. Niepodlegosci Warsaw, Poland, 162: 02-554.

Koh, P. (2003). On the association between institutional ownership and aggressive corporate earnings management in Australia. Br. Account.Rev., 35: 105-128.

Li, K. \& Xinlei, Z. (2008). Asymmetric Information and Dividend Policy, Financial Management, 37(4), 673-694

Lang, L. H. P. \& Stulz, R. M. (1994). Tobin's q, Corporate Diversification and Firm Performance. Journal of Political Economy, 102 (6), 1248-1280.

Manos, R. (2002). Dividend policy and agency theory: Evidence on Indian firms. Finance and development research programme, working paper series, Vol. 41, pp. 1 - 25.

Mork, R., Shleifer, A. \& Vishny, W. (1988). Management Ownership and Market Valuation: An Empirical Analysis. Journal of Financial Economics, 292-315

McConnell, J. J. \& Servaes, H. (1990). Additional Evidence on Equity Ownership and 
Corporate Value. Journal of Financial Economics, 27, 595-612

Maury, C. \& Pajuste, A. (2002). Controlling Shareholders, Agency problems, and Dividend Policy in Finland. Working Paper. Stockholm School of Economics.

Mehrani, M. \& Eskandar, (2011). Ownership structure and dividend policy: Evidence from Iran. African Journal of Business Management Vol. 5(17), pp. 7516-7525.

Miller, M. H. \& Rock, K. (1985). Dividend Policy under Asymmetric Information. Journal of Finance, 40 (4), 1031-1051.

Ramli, N. M. (2010). Ownership Structure and Dividend Policy: Evidence from Malaysian Companies. International Review of Business Research Papers, Vol. 6(1), 170-180.

Rozeff, M. S. (1982). Growth, Beta and Agency Costs as Determinants of Dividend Payout Ratios. Journal of Financial Research 5(3):249-259.

Short, H., Zhang, H., \& Keasey, K. (2002). The link between dividend policy and institutional ownership. J. Corp.Financ., 8: 105-122.

Stouraitis, A. \& Wu L. (2004). The Impact of Ownership Structure on the Dividend Policy of Japanese Firms with Free Cash Flow Problem, AFFI December meeting.

Shah, S.Z.A., Ullah, W. \& Hasnain, B. (2010). Impact of ownership sturcture on dividend policy of firm. International Conference on E-business, Management and Economics, 3: 22-26.

Shleifer, A. \& Vishny, R. (1989). Management Entrenchment: The Case of Manager Specific Investments. Journal of Financial Economics, 25 (1), 123-139

Wiberg, D. (2008). Ownership, Dividends, R\&D and Retained Earnings - are institutional owners short-term oriented? Working paper. The Royal Institute of technology. Centre of Excellence for Science and Innovation Studies (CESIS)

Zeckhauser, R. \& Pound, J. (1990). Are Large Shareholders Effective Monitors? An Investigation of Share Ownership and Corporate Governance, in: R. Hubbard, ed., Asymmetric Information, Corporate Finance and Investment (University of Chicago Press, Chicago) 149-180. 